\title{
MANUFACTURE A SOLAR DRYER FOR DRYING SOME AGRICULTURAL PRODUCTS
}

\author{
Mahmoud M. A. Ali*
}

Moheb M. A. El-Sharabasy*

\begin{abstract}
The objectives of this study were to develop and evaluate a solar dryer for drying by solar energy, determination of the optimum conditions for the solar dryer during the drying process of mango slices, okra slices and mint and comparing the cost of the solar dryer and drying on trays by direct sun. Two experimental groups were carried out for each crop. Every group consists of 9 treatments. The first group of tests was run under different number of trays 4, 5, and 7 trays with different product masses. The second group of tests was run under different number of open holes 5, 7, and 9 holes also with different product masses. It was lower cost for the drying products with obtain to suitable moisture content is (759.9, 934.8 and 1900.6) L.E/Mg under seven open slots, and four trays. In order to minimize drying cost, it is recommended to use the manufactured solar dryer for drying by solar energy for drying mango slices, okra slices and mint under the following conditions: Number of trays of (5 trays), number of open holes of (7 holes) and Mass of product of $(1.25,1.00$ and $0.30 \mathrm{~kg} /$ tray) with okra, mango and mint, respectively.

\section{INTRODUCTION}

$\mathrm{M}$ any different types of fruits, vegetables and aromatic plants have been produced in Egypt because of its suitable climate along the year. Egypt has a high potential solar energy and mean annual bright sunshine hours. According to experimental data, the annual average of global solar radiation is $(5.4-7.1) \mathrm{kW} . \mathrm{h} / \mathrm{m}^{2}$.day, while the annual average of diffuse solar radiation is $(1.8-2.2) \mathrm{kW} . \mathrm{h} / \mathrm{m}^{2}$.day. The annual average of actual sunshine duration is (9.2-11) h. The annual average solar radiation on full tracking system is $(7.5-10.5) \mathrm{kW} \cdot \mathrm{h} / \mathrm{m}^{2}$.day. From these numbers it can be concluded that Egypt has a great potential of solar energy, which can be considered as a reliable energy resource all over the year (N.R.E.A. and U.S.A.I.D. 1991).
\end{abstract}

\footnotetext{
${ }^{*}$ Assist. Prof. of Agric. Eng., Fac. of Agric., Zagazig Univ., Egypt.
} 
Drying process has always been a great importance for conserving agricultural products in agricultural countries like Egypt. Drying process is the most common form of food preservation and extends the food self-life.

It is a simultaneous heat and mass transfer operation in which moisture is removed from food material and carried away by hot air. Open sun drying is a well-known food preservation technique that is still the most common method used to preserve agricultural product in most tropical and subtropical countries. In Egypt, drying is achieved natural method by spreading out the material on the ground especially for grain crops. In this case, there are many disadvantages like low quality and hygienic problems. Being unprotected from windborne dirt and dust, rain, infestation by insects, rodents and other animals, the quality of food is seriously degraded. The resulting loss of food quality in the dried products may have effect negatively trade potential and economical worth. For preventing the deterioration of the materials different types of drying methods have been developed. On the other hand, the conventional dryers are not economic due to high energy cost. For that reason, direct or indirect sun dryers have good opportunity for about quality and efficiency improvement. In this purpose, there have been many studies on the drying behavior of fruits, vegetables and aromatic plants such as mango, apricot, sweet pepper, garlic, tomato, grape, pineapple, tomato, figs, onion, red pepper and mint.... ext. Properly designed solar drying systems must take into account drying requirements of specific crops. Simulation models are needed in the design, construction and operation of drying systems. Awady et al. (1988) constructed two types of solar energy dryers (tent and tray dryers) to dry some agricultural products such as potato, onion, mint, and grape by solar dryer as compared with direct sun they found that the temperature inside the solar tend dryer rises about $3-5{ }^{\circ} \mathrm{C}$ over the ambient temperature and $1{ }^{\circ} \mathrm{C}$ for tray. The results showed that solar tent dryer has the highest drying coefficients. This method is recommended for materials drying to avoid contamination with less time requirement. The solar tent drying was also found least expensive in drying compared with other sources of energy including petroleum, biogas, tray and 
direct sun methods. Madhlopa et al. (2002) designed a solar air heater, comprising two absorber systems in a single flat-plate collector. The heater was integrated to a drying chamber for food dehydration. The performance of the dryer was evaluated by drying fresh samples of mango slices. The air heater converted up to $21.3 \%$ of solar radiation to thermal power, and raised the temperature of the drying air from about 31.7 to $40.1^{\circ} \mathrm{C}$ around noon. The dryer reduced the wet basis moisture content of sliced fresh mangoes from $85 \%$ to $13 \%$ (w.b.) in 3-5 days depending on the weather conditions. Ali (2003) developed a simple dryer for drying some agricultural products. The developed dryer consists of two units namely: a) the receiver in a cylindrical shape contains some circular trays and b) the dish with $150 \mathrm{~cm}$ diameter as a concentrator. He recommended to use the developed solar dryer for drying date palm, potato, and melokhia under the following conditions: dryer height of $(90 \mathrm{~cm})$, distance between receiver and concentrator of $(100 \mathrm{~cm})$, number of trays of (4 trays), number of open holes of (12holes), and mass of product of $(0.5,0.3$, and $0.2 \mathrm{~kg} /$ tray $)$ with date palm, potato and melokhia, respectively to give the best results. EL-Amin et al. (2005) designed and constructed a solar dryer with $1.03 \mathrm{~m}^{2}$ solar collector area for mango slices drying under controlled conditions (laboratory dryer). The average ambient conditions are $30^{\circ} \mathrm{C}$ air temperature and $15 \%$ relative humidity with daily global solar radiation incident on horizontal surface of about $20 \mathrm{MJ} / \mathrm{m}^{2} /$ day. The designed dryer with a collector area of $16.8 \mathrm{~m}^{2}$ is expected to dry $195.2 \mathrm{~kg}$ fresh mango (100kg of sliced mango) from $81.4 \%$ to $10 \%$ wet basis in two days under ambient conditions during harvesting period from April to June. Singh et al. (2005) studied the performance of solar tunnel dryer for drying unripe peeled mango. They reported that air temperature inside the dryer could be maintained in the range of $50-75^{\circ} \mathrm{C}$ on typical sunny days. Cut mango pieces with initial moisture content of $79 \%$ were dried in four and half days to a moisture level of $4.2 \%$ as compared to ten days in open drying to a moisture content of $4.7 \%$. They observed the average drying temperature in the tunnel was $60^{\circ} \mathrm{C}$ and quality of the product dried in the tunnel dryer was found to be superior to the sun-dried product in terms of microbial load, appearance 
and acceptability. Dadashzadeh (2006) developed a dryer to dry grapes, results showed that by using this dryer, the duration of drying with this method can be decreased from 10-12 days in traditional method to 4-5 days and can obtain higher quality than the traditional method. Ali (200^) developed a solar device for drying some crops; determined the optimum conditions for drying garlic and red pepper, and compared the cost use of the solar dryer with the sun drying. Three experimental testes were under different dryer heights of 90,95 , and $100 \mathrm{~cm}$, different number of trays of 5 , 6 , and 9 trays and different numbers of open holes of 10, 13, and 16 holes. The obtained results recommended to use the developed sun dryer for drying garlic and red pepper dryer height of $95 \mathrm{~cm}$, number of trays of 6 trays, number of open holes of 13 holes and product mass of 0.6 and $0.75 \mathrm{~kg} / \mathrm{tray}$ with garlic and red pepper, respectively. Alonge and Hammed (2007) designed, constructed and tested a direct passive solar dryer in such a way that the angle of inclination of the collector could be varied depending on the location and season. The dryer was tested under no load and load conditions. The results of no load test conditions gives the maximum of $59^{\circ} \mathrm{C}$ inside the dryer, while outside the dryer was $38^{\circ} \mathrm{C}$. The solar dryer was placed at an angle of $26^{\circ}$ to the horizontal and used to dry $2160 \mathrm{~g}$ of Yam chips with an initial moisture content of $62 \%$ (wet basis) to a final moisture of $11.11 \%$ (wet basis). The drying time of the Yam chips during the test was 26 sunshine hours as compared with 36 hours in open air. Ajao and Adedeji (2008) made a simple solar dryer $(1500 \times 750 \times 620, \mathrm{~mm}$ in dimension) of wood and double layered transparent glass which serves as a solar collector that brings about the transformation of solar radiation to heat energy needed for proper drying process inside the dryer. They found that the rate of drying of crop samples in the solar dryer was higher than in the open sun. The assessment of the drying rate of the crops in the solar dryer and in open-sun gives an average of $9.4 \mathrm{~g} / \mathrm{h}$ and $8.6 \mathrm{~g} / \mathrm{h}$ for yam (sliced), 9.1 $\mathrm{g} / \mathrm{h}$ and $7.8 \mathrm{~g} / \mathrm{h}$ for maize, $5.9 \mathrm{~g} / \mathrm{h}$ and $5.4 \mathrm{~g} / \mathrm{h}$ for okra while that of pepper is $1.6 \mathrm{~g} / \mathrm{h}$ and $1.3 \mathrm{~g} / \mathrm{h}$ respectively with an average dryer efficiency of $18 \%$. Bala (2009) demonstrated the potentialities of solar tunnel dryer, greenhouse type solar dryer and roof integrated solar dryer for production of 
quality dried fruits, vegetables, spices, medicinal plants and fish. The drying air temperature for a product must not exceed the maximum permissible drying air temperature. The maximum permissible temperature for production of quality dried pineapple, mango, jackfruit and chili is $65^{\circ} \mathrm{C}$ and that of fish is $52^{\circ} \mathrm{C}$. But for herbal and medicinal plants a maximum temperature of $100^{\circ} \mathrm{C}$ is recommended for glycoside species, $65^{\circ} \mathrm{C}$ for mucilage species and 35 to $45^{\circ} \mathrm{C}$ for essential-oil species. This drying air temperature can be achieved by simply adjusting collector length (in solar tunnel dryer) or air flow rate by changing the number of fans in operation. Yahya (2010) used a solar assisted drying system for drying the herbal tea or green tea. The drying system has an array of collector with the size of $13.8 \mathrm{~m}^{2}$. The fresh tealeaves form the plantations are first soaked in warm water for five minutes. Next, water from the tealeaves will be drained out and dried in the chamber. The collector is of the V-groove type. The system has two fans to circulate air. A $10 \mathrm{~kW}$ auxiliary heater is also included and will be on if the temperature of the drying chamber is less than the specified preset temperature of $50^{\circ} \mathrm{C}$. A drying chamber of $55^{\circ} \mathrm{C}$ can be reached at solar radiation levels of $600-700 \mathrm{~W} / \mathrm{m}^{2}$ and ambient temperature of $27-34^{\circ} \mathrm{C}$. The flow rate is fixed at $15.1 \mathrm{~m}^{3} / \mathrm{min}$. The initial moisture content is $87 \%$ (wet basis) and the final moisture content is $54 \%$ (wet basis). A total of 12 hours of drying time is required where solar energy contribute about 56\% the total energy requirement. This study was undertaken to investigate drying characteristics of some agricultural products in a new designed solar dryer.

\section{MATERIALS AND METHOD}

The main experiments were carried out during the summer season of 2012 at Faculty of agriculture, Zagazig city, Sharkia Governorate to investigate the use of solar energy as a source of drying some different agricultural crops. All experiments were conducted using a developed solar dryer.

\subsection{MATERIALS:}

\subsubsection{Agricultural products:}

Three different agricultural products were used for drying with direct sun and with the developed dryer as following: 
- Mango: Before drying with direct sun or loading into solar dryer, mango is peeled and cut into small slices with thickness of about $3 \mathrm{~mm}$ in average.

- Okra: Before drying with direct sun or loading into solar dryer, okra is washed, its head is removed and then cut into two or three pieces with average thickness of $5 \mathrm{~mm}$. The following treatments can be applied for solar drying: using $2 \% \quad \mathrm{Na}_{2} \mathrm{~S}_{2} \mathrm{O}_{5}$ dipping as a pretreatment and blanching of okra needs ice-bath dipping before drying.

- Mint: Before drying with direct sun or loading into solar dryer, mint leaves are first soaked in warm water for five minutes. Next, drained out the water from the mint leaves, then loading into the solar dryer.

\subsubsection{The developed dryer:}

The developed dryer for collecting solar energy was designed for drying mango slices, okra and mint leaves. It made from iron sheet with thickness of $1 \mathrm{~mm}$ and coated with black color to increase its absorptivity of the solar radiation. The solar dryer consists of the main chamber having six faces, each face was rectangular in shape and having dimensions of $(400 \times 800 \mathrm{~mm})$ as shown in Fig. 1. Choosing the hexagonal shape of the main drying chamber was due to the following reasons:

- It has absorptive area larger than the cylindrical shape.

- It has three absorptive rectangular faces towards the sunshine.

- Easy to open and close for loading and removing trays after each treatment.

The main chamber of solar dryer contains seven trays with perforated bottom to carry the products. Each tray consists of two parts: the fixed parts as two triangular in shape with area of $\left(0.146 \mathrm{~m}^{2}\right)$ and the moving part as triangular in shape with area of $\left(0.293 \mathrm{~m}^{2}\right)$. 


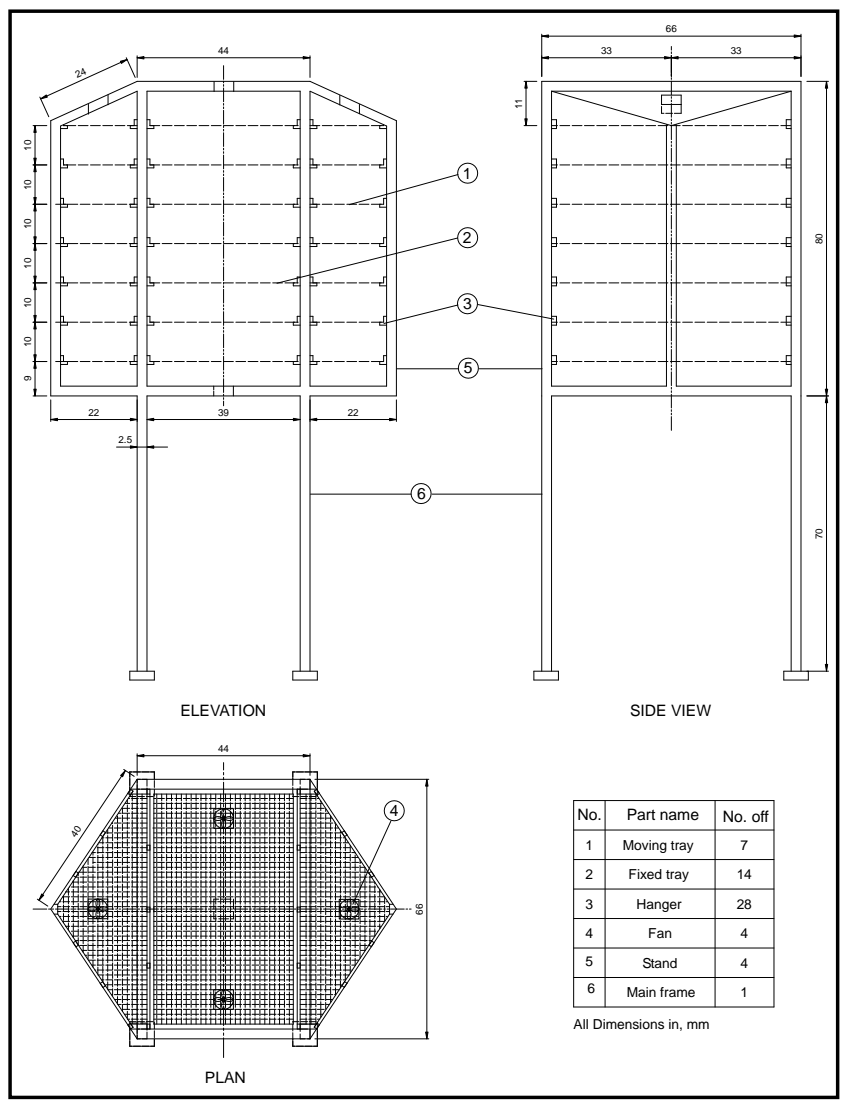

Fig. 1. The elevation, side view and plan of the developed solar dryer.

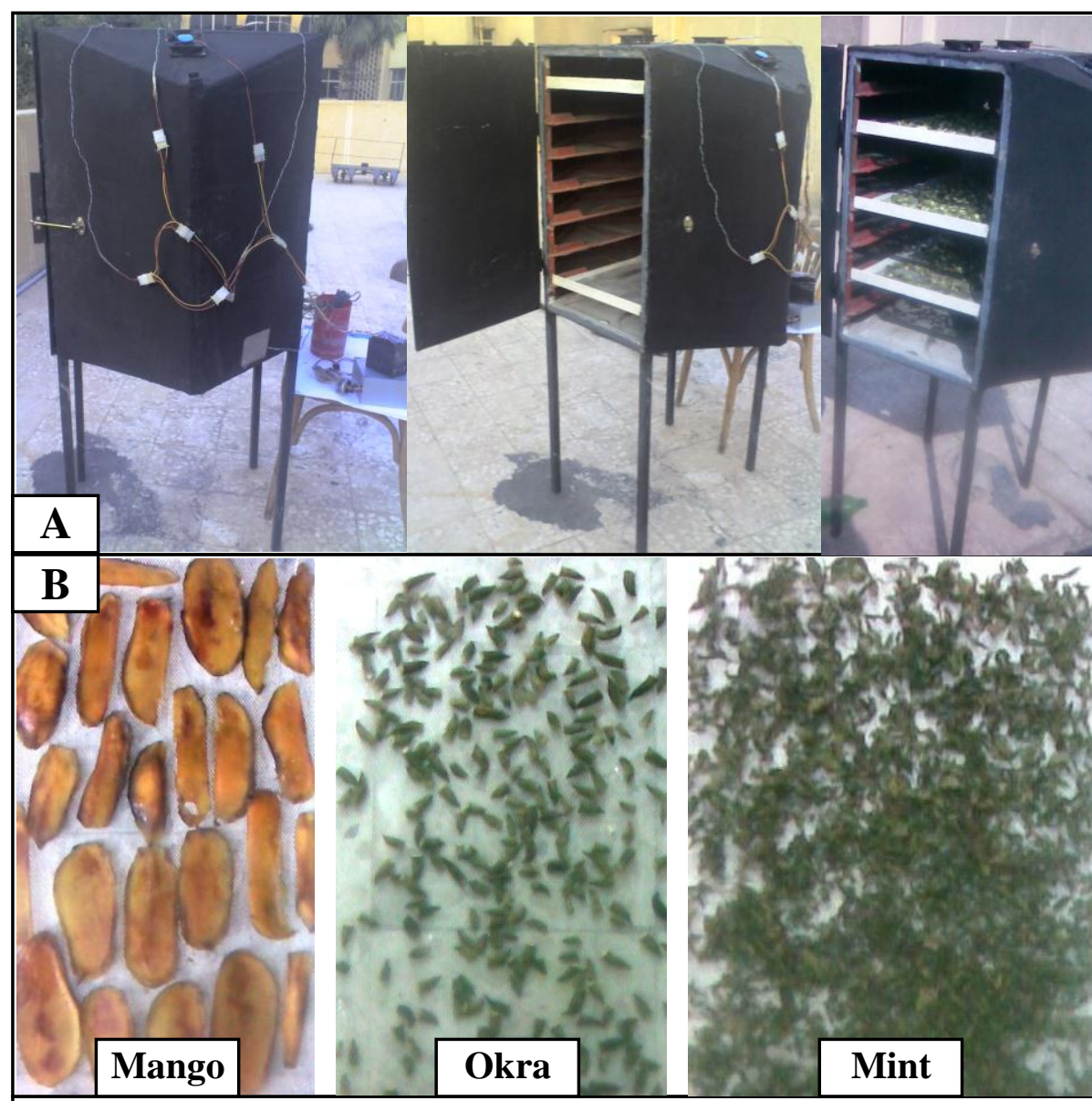

Fig. 2. (A): Photo of the developed solar dryer. (B): Photo of the products after dying using the developed solar dryer. 
The two parts of one tray gave the hexagonal shape with a total area of $\left(0.439 \mathrm{~m}^{2}\right)$ which could be loading with an adequate agricultural products. The main chamber of solar dryer is also contains nine square holes distributed as follow: four holes were in the top side of the drying chamber included four fans to circulate air, the five other holes were in the bottom and the side of drying chamber to allow the air flow rate at $15.1 \mathrm{~m}^{3} / \mathrm{min}$. The specifications of the drying chamber and its trays are given in Table 1.

\subsection{METHOD:}

Experiments were conducted to evaluate the developed solar dryer for drying mango slices, okra and mint leaves comparing with direct sun drying. The experimental studies have been done in the summer season of 2012. Two experimental groups, namely A and B were carried out for each product. Every group consists of six treatments as following:

A- The first group of tests was carried out under different numbers of trays of 4 , 5 and 7 trays with different masses of product namely: $0.75,1.00$ and 1.25 $\mathrm{kg} /$ tray for mango slices; $1.00,1.25$ and $1.50 \mathrm{~kg} /$ tray for okra; and $0.20,0.30$, and $0.40 \mathrm{~kg} /$ tray for mint leaves. The variations of moisture content with drying times were recorded.

B- The second group of tests was carried out under different numbers of open holes of 5, 7 and 9 holes with different masses of product namely: 0.75, 1.00 and $1.25 \mathrm{~kg} /$ tray for mango slices; $1.00,1.25$ and $1.50 \mathrm{~kg} /$ tray for okra; and 0.20 , 0.30 , and $0.40 \mathrm{~kg} /$ tray for mint leaves. The variations of moisture content with drying times were recorded.

\subsection{MEASUREMENTS:}

\subsubsection{Solar radiation measurements:}

WatchDog weather station (Model 900ET) has mainly 6 internal sensors. It can record and monitor real-time local weather information. Where, it can record Solar Radiation (SRD), Temperature (TMP), Wind Speed (WNS), Wind Direction (WND), Relative Humidity (HMD) and Rainfall (RNF).

\subsubsection{Temperature measurement:}

The temperatures in this research were measured by copper-constantan (type $\mathrm{T}$ ) thermocouples. Sixteen thermocouples junctions were used to measure the temperature. The solar collectors were fitted with copper-constantan (type T) thermocouples to measure the inlet and outlet temperature and the absorber temperature at different locations. All thermocouples in various locations in the test rig were calibrated from ice point to water boiling point temperature at 
atmospheric pressure. The cold junction was kept immersed in an ice bath. The temperature wires were connected to a manual selector switch and a digital multimeter. The millivolt $(\mathrm{mV})$ output signals of each thermocouple corresponding to each reference temperature were measured using a digital multimeter at accuracy of $\pm 0.05{ }^{\circ} \mathrm{C}$. Calibration curves between output signals of thermocouple $(\mathrm{mV})$ and the calibrated temperature was constructed. The calibration curve of thermocouple No.4 as an example, is show in Fig. 3. The mean slopes $\left({ }^{\circ} \mathrm{C} / \mathrm{mV}\right)$ of the thermocouples are listed in Table 1 .

Table 1: the mean slopes $\left({ }^{\circ} \mathrm{C} / \mathrm{mV}\right)$ of the thermocouples.

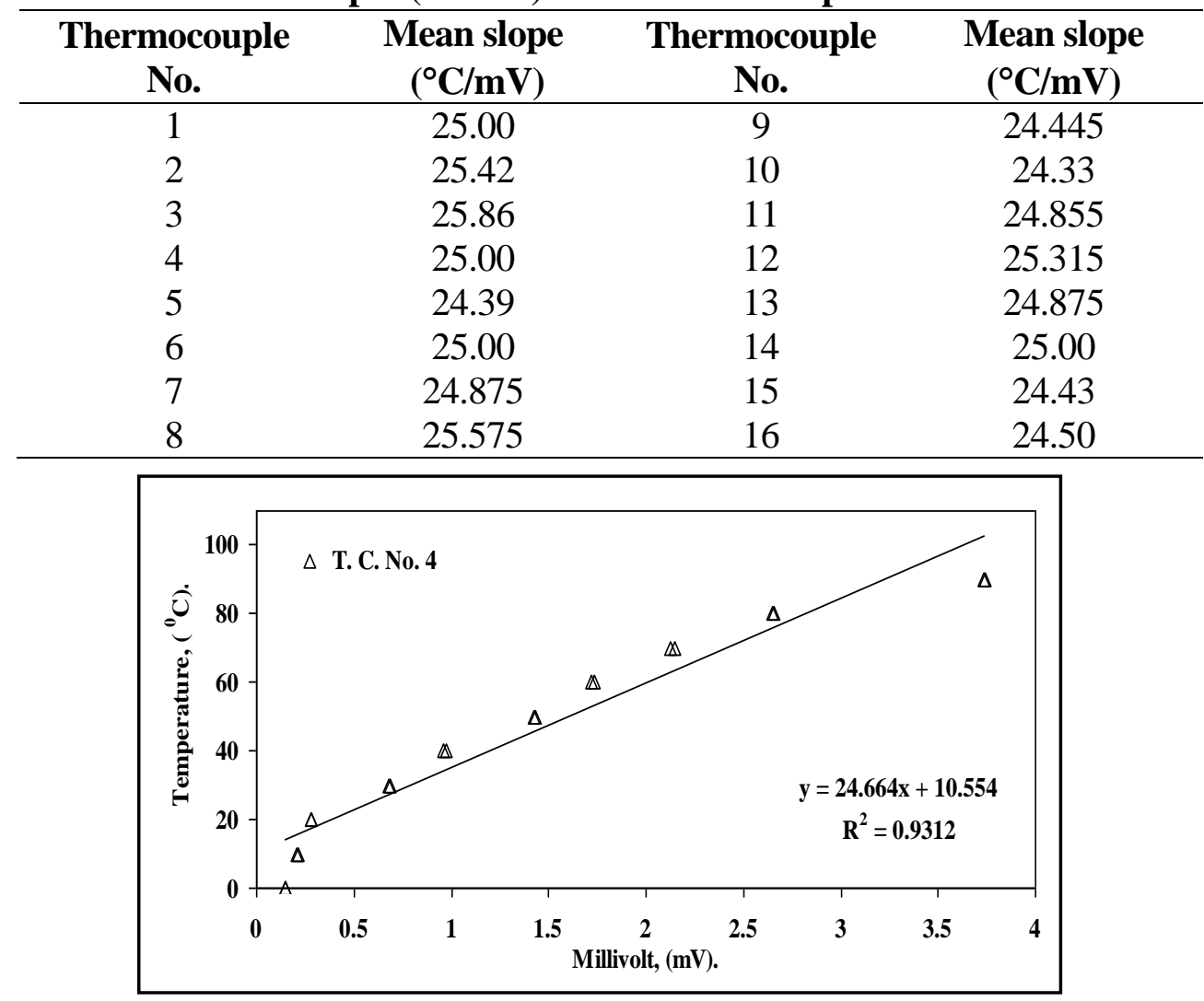

Fig.3: Calibration curve for a thermocouples.

\subsubsection{Moisture content (\%):}

Mass of products was measured by using electric balance before and after drying each treatment. Moisture content (\%) was estimated on wet bulb (w.b) according to the following equations:

$$
\text { M.C. }(w b)=\frac{(\mathrm{W}-\mathrm{d})}{\mathrm{W}},(\%)
$$

M.C. (wb): Percentage of moisture content, (wet bulb), (\%); 
W: Mass of wet sample, g;

$\mathrm{d}$ : Mass of dry material in the sample, $\mathrm{g}$.

\subsubsection{Efficiency of solar dryer:}

Efficiency of solar dryer was calculated as follows:

$$
E=\frac{Q_{u}}{Q_{i}} \quad,(\%)
$$

E: Efficiency of solar dryer.

$\mathbf{Q}_{\mathbf{u}}$ : The useful heat.

$\mathbf{Q}_{\mathrm{i}}$ : The incident radiation.

$$
\mathrm{Q}_{\mathrm{u}}=\mathrm{m}_{\mathrm{r}} \mathrm{L}+\mathrm{m}_{\mathrm{p}} \mathrm{c}_{\mathrm{p}} \Delta \mathrm{t}
$$

$\mathbf{m}_{\mathbf{r}}$ : Mass of moisture removal, $\mathrm{kg}$.

$\mathbf{L}$ :Latent heat of water. It was taken $2257 \mathrm{~kJ} / \mathrm{kg}$. (Awady, 1993).

$\mathbf{m}_{\mathbf{p}}$ : Mass of agricultural product, $\mathrm{kg}$.

$\mathbf{c}_{\mathbf{p}}$ : Specific heats of the agricultural product.

$\Delta \mathbf{t}$ : Temperature rise of agricultural product, ${ }^{\circ} \mathrm{C}$.

\subsubsection{Drying cost:}

The hourly cost of direct sun drying as well as drying using developed solar dryer with trays was calculated according to the formula developed by (Awady, 1978) as follows:

$$
\mathrm{C}=\frac{\mathrm{P}}{\mathrm{h}}\left(\frac{1}{\mathrm{a}}+\frac{\mathrm{i}}{2}+\mathrm{t}+\mathrm{r}\right)+(\mathrm{W} \cdot \mathrm{e})+\frac{\mathrm{m}}{144}
$$

Where:

$\mathrm{C}=$ Hourly cost, L.E/h.

$\mathrm{h}=$ Yearly working hours, $\mathrm{h} /$ year.

$\mathrm{i}=$ Interest rate/year.

$\mathrm{t}=$ Taxes, over heads ratio.

$\mathrm{m}=$ Monthly average wage, $\mathrm{L} . \mathrm{E}$

$\mathrm{W}=$ Electrical power, $\mathrm{kW}$.
$\mathrm{P}=$ Price of machine, L.E.

$\mathrm{a}=$ Life expectancy of the machine, $\mathrm{h}$.

$\mathrm{e}=$ Hourly cost $/ \mathrm{kW} \cdot \mathrm{h}$.

$\mathrm{r}=$ Repairs and maintenance ratio.

$\mathrm{S}=$ Specific fuel consumption, $1 / \mathrm{hp} . \mathrm{h}$.

$144=$ Reasonable estimation of monthly working hours.

The cost per unit of production was determined by using the following formula:

$$
\text { Cost perunit of production }=\frac{\text { Hourly } \operatorname{cost}(\mathrm{L} . \mathrm{E} / \mathrm{h})}{\text { Productivity }(\mathrm{Mg} / \mathrm{h})},(\mathrm{L} \cdot \mathrm{E} / \mathrm{Mg})
$$

\section{RESULTS AND DISCUSSION}

Experiments were carried out with the purpose of evaluating the developed solar dryer. Experiments were also carried out to compare between both solar and sun drying. 


\subsection{Some parameters affecting on removal moisture content:}

The reduction of moisture content by solar energy using the developed dryer depends on several factors such as: number of trays and number of open holes. Each of these factors will be discussed as follows:

\subsubsection{Effect of number of dryer trays on removal moisture content comparing with direct sun drying:}

Results showed that the reduction of moisture content is greatly affected by the number of trays for all products. Results in Fig.4. show that the maximum removal rate of moisture content is obtained at five trays for the three products under studying at different product masses. Concerning mango slices, Fig.4. show that after twelve drying hours from (9 Am to $5 \mathrm{Pm}$ and 9 Am to $1 \mathrm{Pm}$ in the next day), product moisture content decreased by 75.33, 90.33, 89.30 and $86.38 \%$ with product mass of $0.75 \mathrm{~kg} /$ tray, also decreased by $73.99,89.43,88.53$ and $83.63 \%$ with product mass of $1.00 \mathrm{~kg} /$ tray, and decreased by $70.48,88.23$, 86.72 and $82.02 \%$ with product mass of $1.25 \mathrm{~kg} /$ tray under direct sun drying, solar dryer at number of trays of 4,5, and 7 trays, respectively. Relating to okra slices, Fig.4. show that after sixteen drying hours from (9 Am to $5 \mathrm{Pm}$ and $9 \mathrm{Am}$ to $5 \mathrm{Pm}$ in the next day), product moisture content decreased by $79.41,92.79$, 91.39 and $86.70 \%$ with product mass of $1.00 \mathrm{~kg} /$ tray, also, decreased by 78.41 , $91.94,89.78$ and $85.78 \%$ with product mass of $1.25 \mathrm{~kg} /$ tray, and decreased by $77.06,90.64,88.44$ and $82.77 \%$ with product mass of $1.50 \mathrm{~kg} /$ tray under the same previous conditions. As to mint, Fig.4. show that after eight drying hours from (9 Am to $5 \mathrm{Pm}$ ), product moisture content decreased by $80.58,91.08,89.73$ and $84.78 \%$ with product mass of $0.2 \mathrm{~kg} /$ tray, also decreased by $75.59,85.67$, 83.71 and $80.66 \%$ with product mass of $0.3 \mathrm{~kg} /$ tray, and decreased by 73.47 , $83.69,80.84$ and $78.09 \%$ with product mass of $0.4 \mathrm{~kg} /$ tray under the same previous conditions.

\subsubsection{Effect of number of open holes of dryer on removal moisture content comparing with direct sun drying:}

The maximum removal rate of moisture content is obtained at a number of open holes of seven holes for the three products at any product mass. This attributed to the temperature, which reached the highest value under seven opens. Results showed that the reduction of moisture content is greatly affected by the number of open holes for all products. Concerning mango slices, Fig.5. show that after twelve drying hours from (9 Am to $5 \mathrm{Pm}$ and 9 Am to $1 \mathrm{Pm}$ in the next day), product moisture content decreased by $76.24,89.82,90.97$ and $86.79 \%$ with 
product mass of $0.75 \mathrm{~kg} /$ tray, also decreased by $72.91,88.33,88.79$ and $82.31 \%$ with product mass of $1.00 \mathrm{~kg} / \mathrm{tray}$, and decreased by $69.25,86.36,87.45$ and $81.09 \%$ with product mass of $1.25 \mathrm{~kg} /$ tray under direct sun drying, solar dryer at number of open holes of 5, 7, and 9 open holes, respectively
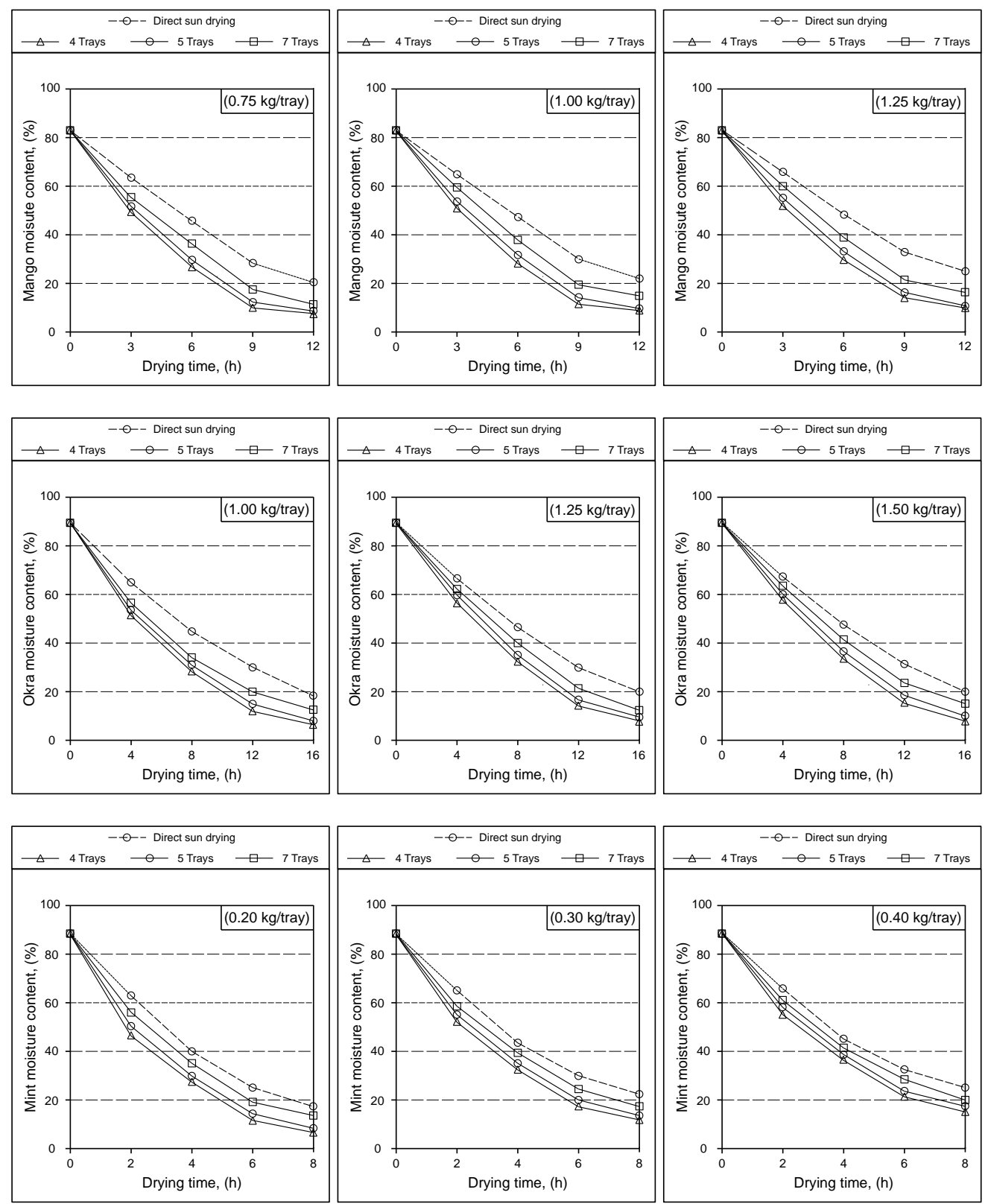

Fig.4: Effect of drying time on product moisture content under direct sun drying and developed dryer with different tray numbers and different product masses at seven open holes. 

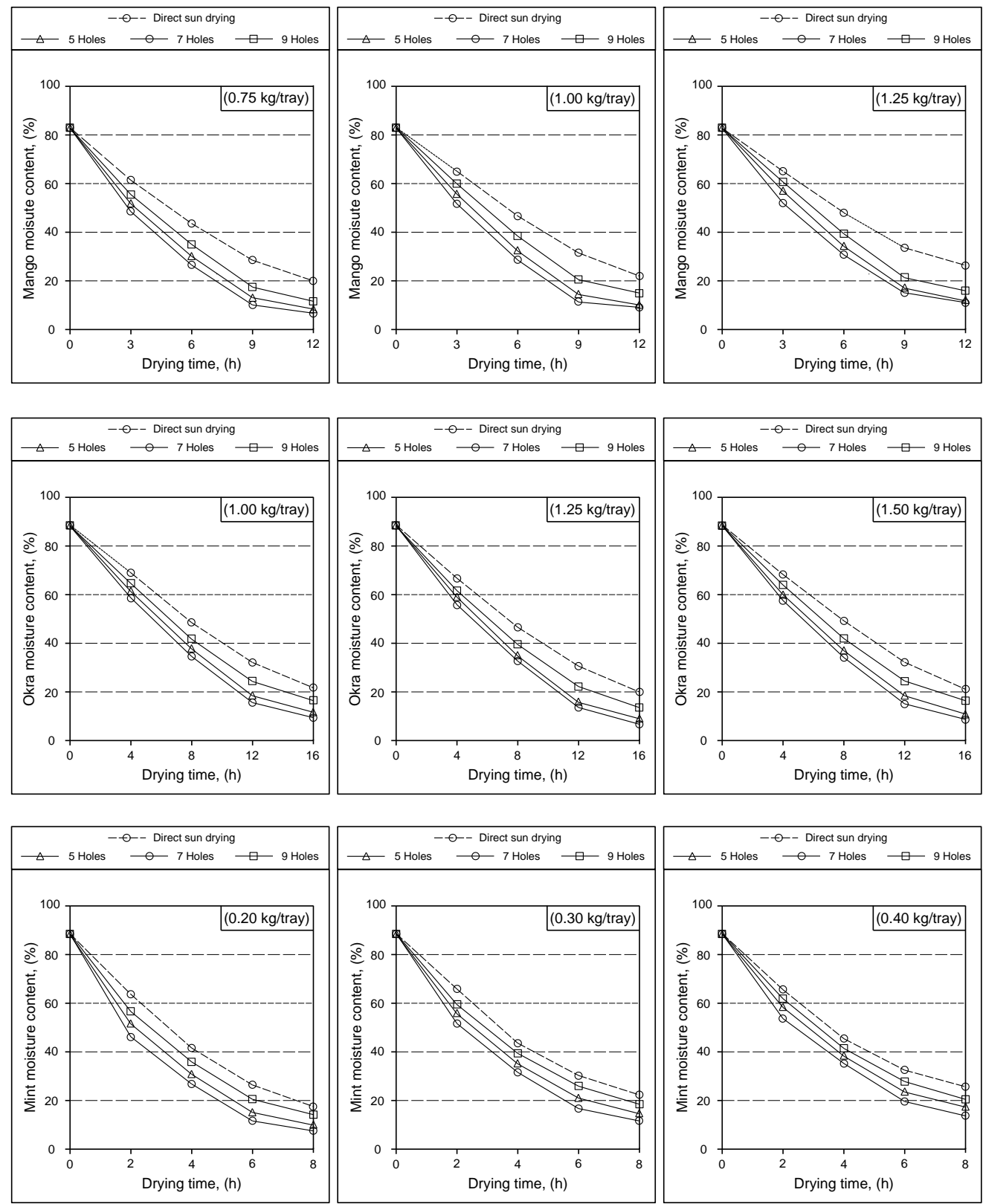

Fig.5: Effect of drying time on product moisture content under direct sun drying and developed dryer with different open holes numbers and different product masses at five trays.

Relating to okra slices, Fig.5. show that after sixteen drying hours from (9 Am to $5 \mathrm{Pm}$ and $9 \mathrm{Am}$ to $5 \mathrm{Pm}$ in the next day), product moisture content decreased by $78.54,91.71,92.66$ and $86.19 \%$ with product mass of $1.00 \mathrm{~kg} /$ tray, also, decreased by $77.74,90.19,91.58$ and $85.36 \%$ with product mass of $1.25 \mathrm{~kg} /$ tray, 
and decreased by $76.38,88.02,90.24$ and $81.82 \%$ with product mass of 1.50 $\mathrm{kg} /$ tray under the same previous conditions. As to mint, Fig.5. show that after eight drying hours from ( $9 \mathrm{Am}$ to $5 \mathrm{Pm}$ ), product moisture content decreased by $80.35,89.16,90.97$ and $83.89 \%$ with product mass of $0.2 \mathrm{~kg} /$ tray, also decreased by $74.85,84.00,85.89$ and $79.09 \%$ with product mass of $0.3 \mathrm{~kg} /$ tray, and decreased by $71.71,81.03,85.10$ and $77.08 \%$ with product mass of 0.4 $\mathrm{kg} /$ tray under the same previous conditions. Results also show that the maximum removal rate of moisture content is obtained at a number of open holes of seven holes for the three products at any product mass. This attributed to the temperature, which reached the highest value under seven opens.

\subsection{Efficiency of solar dryer :}

The efficiency with which solar energy can be converted into more useful forms is one of the most important parameters concerning its utilization as available source of energy. Temperatures of solar dryer were measured by thermocouples input and output dryer in August, September and October. On 5/8/2012 temperature value increased by $44.2{ }^{\circ} \mathrm{C}$ comparing with ambient temperature, on 19/9/2012 temperature value increased by $41^{\circ} \mathrm{C}$ comparing with ambient temperature and on 15/10/2012 temperature value increased by $38.5^{\circ} \mathrm{C}$ comparing with ambient temperature under the optimum conditions.

Solar radiation was measured in August, September and October; on $5 / 8 / 2012$. It is found that average solar radiation was about $506 \mathrm{~W} / \mathrm{m}^{2}$, on $19 / 9 / 2012$, average solar radiation was about $472.67 \mathrm{~W} / \mathrm{m}^{2}$ and on $15 / 10 / 2012$, average solar radiation was about $405.33 \mathrm{~W} / \mathrm{m}^{2}$.

Fig.6 show that, the efficiency of solar dryer values calculated on 5/8/2012 under the optimum conditions for drying mango were 29.31, 19.14, 22.35 and $30.21 \%$, with drying times of 2, 4, 6 and 8 (h), respectively.

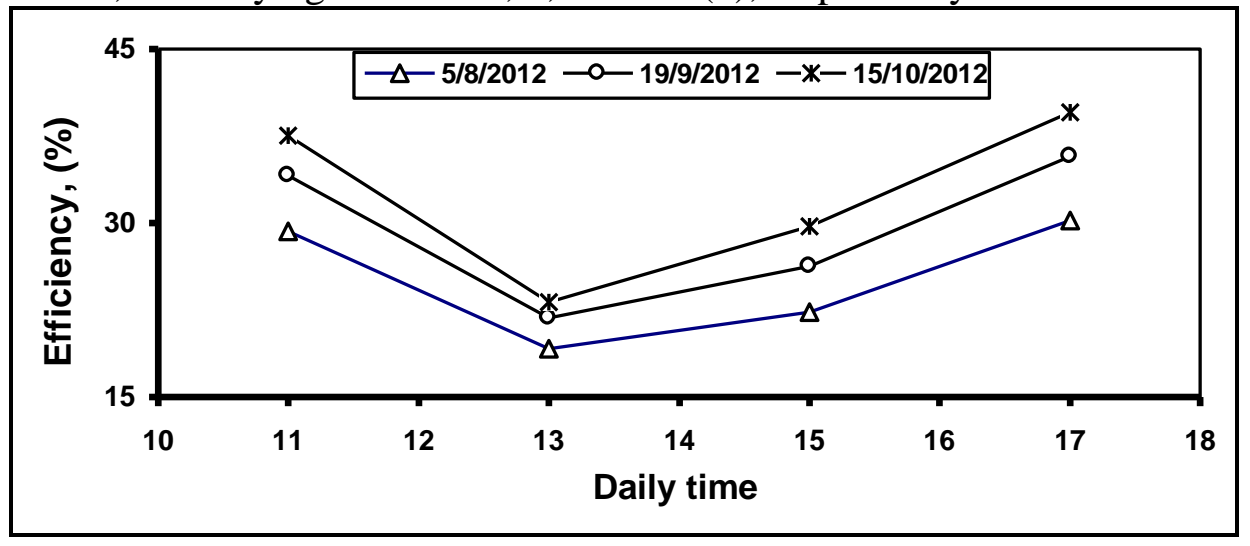

Fig.6: The efficiency of solar dryer on August, September and October. 
Relating to efficiency of solar dryer values calculated on 19/9/2012 under the optimum conditions for drying okra were 34.12, 21.84, 26.24 and $35.76 \%$, with drying times of 2, 4, 6 and $8(\mathrm{~h})$, respectively. As to efficiency of solar dryer values calculated on 15/10/2012 under the optimum conditions for drying mint were $37.51,23.16,29.74$ and $39.58 \%$, with drying times of 2, 4, 6 and 8 (h), respectively.

\subsection{Cost requirements for different drying products:}

The cost of the different drying systems is dependent on many factors due to drying conditions and drying systems.

\subsubsection{Effect of number of dryer trays on drying cost comparing with direct sun drying:}

Fig.7. represent the cost per unit of production for direct sun drying by trays and solar dryer at different number of trays under different mass of products. Cost values of drying mango slices were 2184, $1304.4,1117.2$ and $886.8 \mathrm{L.E} / \mathrm{Mg}$; 1639, 949.8, 834.7 and 661.2 L.E/Mg and 1309.7, 746.9, 651.3 and 511.6 L.E/Mg at product mass of $0.75,1.00$ and $1.25 \mathrm{~kg} /$ tray, respectively under direct sun drying by trays and solar dryer at number of trays 4, 5, and 7 trays, respectively. The best of all treatments are 5 trays and $1.00 \mathrm{~kg} /$ tray because the final moisture content for seven trays was still high. Relating to drying cost of okra slices, the cost values were 2185.4, 1185.6, 1009.2 and 848.6 L.E/Mg; 1746.3, 1165.3, 986.9 and 827.6 L.E/Mg and 1456, 980.1, 834.7 and 706.7 $\mathrm{L} . \mathrm{E} / \mathrm{Mg}$ at product mass of $1.00,1.25$ and $1.50 \mathrm{~kg} /$ tray, respectively under the same previous conditions. The best of all treatments are 5 trays and $1.25 \mathrm{~kg} /$ tray because the final moisture content for seven trays was still high. As to the drying cost of mint, cost values were 5443, 3529.8, 3035.2 and 2574.5 L.E/Mg; 3640, 2398.4, 2059.6 and 1675 L.E/Mg and 2734.3, 1856.4, 1612.4 and 1327.9 L.E/Mg at product mass of $0.20,0.30$ and $0.40 \mathrm{~kg} /$ tray, respectively under the same previous conditions. The best of all treatments are five trays and 0.30 $\mathrm{kg} /$ tray because the final moisture content for seven trays was still high, because the value of removed water decreased, comparing with 5, 7 trays, but 5 trays are considered the best taking in consideration productivity and cost of drying.

\subsubsection{Effect of number of open holes of dryer on drying cost comparing with direct sun drying:}

Fig.7. represented the cost per unit of production for direct sun drying by trays and developed dryer at different numbers of open holes under different mass of products. Relating to the cost for drying mango slices, cost values were 2329.6, 


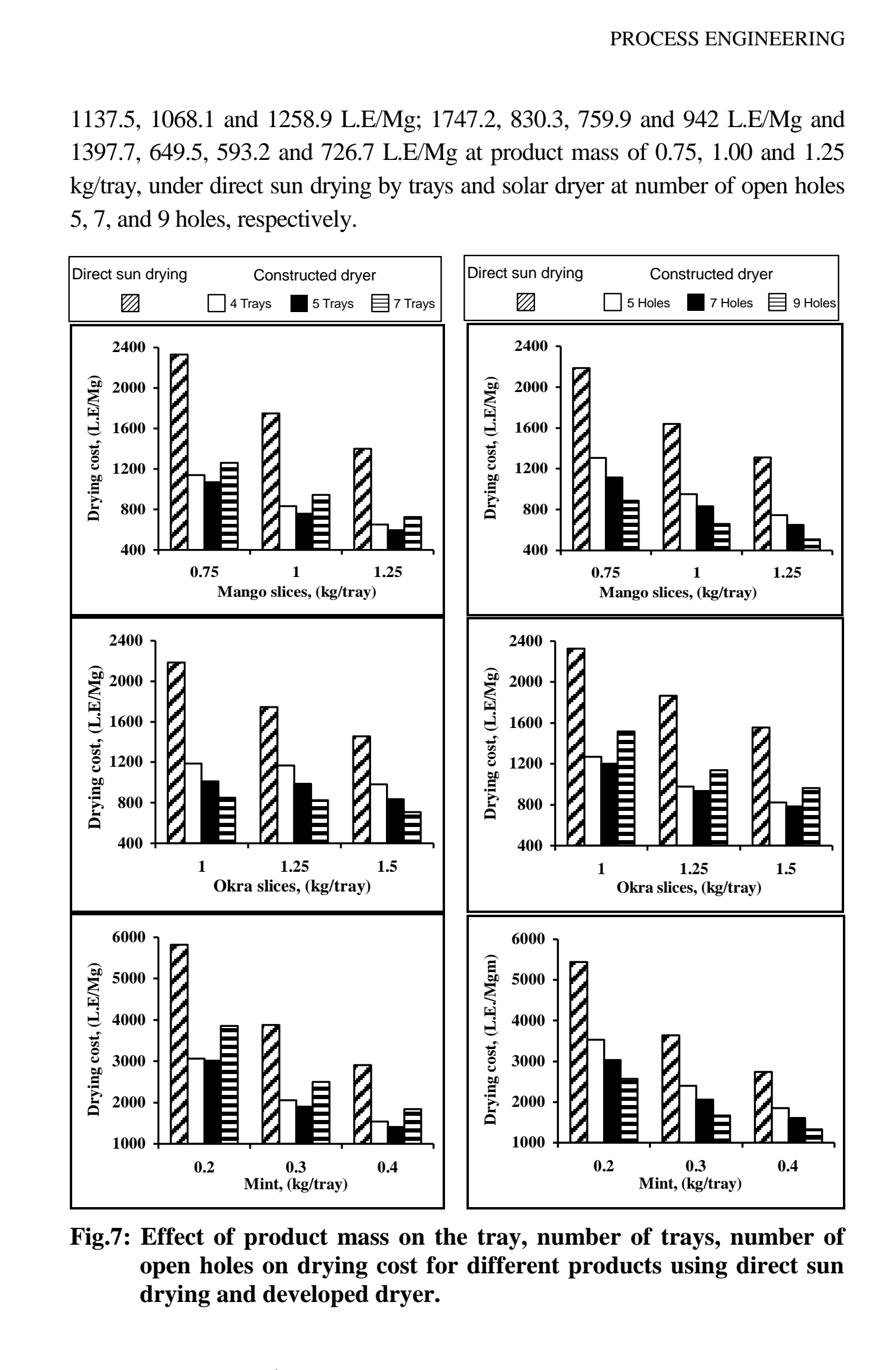


The cost values for drying okra slices were 2329.6, 1269.4, 1202.2 and 1517.6 L.E/Mg; 1863.7, 979.1, 934.8 and 1136 L.E/Mg and 1553.1, 823.8, 783.4 and 962.6 L.E/Mg at product mass of $1.00,1.25$ and $1.50 \mathrm{~kg} /$ tray, under the same previous conditions. As to cost of drying mint, cost values were 5824, 3067.7, 3019 and 3853.6 L.E/Mg; 3882.7, 2059.6, 1900.6 and 2496.8 L.E/Mg and 2912, 1544.7, 1411.9 and 1837.4 L.E/Mg at product mass of $0.2,0.3$ and $0.4 \mathrm{~kg} /$ tray, under the same previous conditions. It is noticed that number of open holes of 7 holes recorded the lowest value of cost per unit production under all products, because the temperature reached the maximum value under 7 open holes.

\section{CONCLUSION}

It is clear from the results the following: after twelve drying hours, the maximum decrease in moisture content of mango slices were $90.33,89.43$ and 88.23 with product mass of $0.75,1.00$ and $1.25 \mathrm{~kg} /$ tray, respectively, after sixteen drying hours, the maximum decrease in moisture content of okra slices were $92.79,91.94$ and 90.64 with product mass of $1.00,1.25$ and $1.50 \mathrm{~kg} /$ tray, respectively, after eight drying hours, the maximum decrease in moisture content of mint were $91.08,85.67$ and 83.69 with product mass of $0.2,0.3$ and $0.4 \mathrm{~kg} /$ tray, respectively All previous results obtained with 4 trays and 7 open holes. It is also clear from the results the following: after twelve drying hours, the maximum decrease in moisture content of mango slices were 90.97, 88.79 and 87.45 with product mass of $0.75,1.00$ and $1.25 \mathrm{~kg} /$ tray, respectively, after sixteen drying hours, the maximum decreased in moisture content of okra slices were $92.66,91.58$ and 90.24 with product mass of $1.00,1.25$ and $1.50 \mathrm{~kg} / \mathrm{tray}$, respectively, after eight drying hours, the maximum decrease in moisture content of mint were $90.97,85.89$ and 85.10 with product mass of $0.2,0.3$ and $0.4 \mathrm{~kg} /$ tray, respectively All previous results obtained with 7 open holes and 4 trays. In order to minimize drying cost, it is recommended to use the device for drying by solar energy for drying mango slices, okra slices and mint under the following conditions: Number of trays of ( 5 trays), number of open holes of (7 holes) and Mass of product of $(1.25,1.00$ and $0.30 \mathrm{~kg} /$ tray) with okra, mango and mint, respectively.

\section{REFERENCES}

Ajao, K. R. and A. A. Adedeji (2008): Assessing the Drying rates of some Crops in Solar Dryer. (Case Study: Vegetables, tuber and grain crops). Journal of Research information in Civil Engineering, Vol.5, No.1, 2008. 
Ali, M. M. A. (2003): Development of a simple device for drying some agricultural products. PH. D. thesis. Department of Agricultural Engineering, Faculty of Agriculture, Zagazig University.

Ali, M. M. A. (2008): Manufacture of a solar dryer for drying garlic and red pepper (Chili). Egypt J. of App. Sci., 23 (3):407-425.

Alonge, A. F. and R. O. Hammed (2007): A direct passive solar dryer for tropical crops. African crop science conference proceeding. Vol. 8. pp: 1643-1646.

Awady, M. N. (1978): Tractor and farm machinery. Text book, Faculty of Agriculture, Ain-Shams University. Pp: 164-167.

Awady, M. N; M. M. Moustafa, A. M. El-Gindy and M. A. El-Genaidy (1988): A trial on solar energy drying for agricultural products with simple setup. Misr, J. Agric. Eng. 5 (3): 377-392.

Awady, M. N; S. A. Mohamed; A. S. El-Sayed and A. A. Hassanain, (1993): Utilization of solar energy for drying processes of Agricultural products. Misr, J. Agric. Eng. 10 (4): 794-804.

Bala, B. K. (2009): Solar drying of fruits, vegetables, spices, medicinal plants and fish: Developments and Potentials. International Solar Food Processing Conference 2009.

Dadashzadeh, M. (2006): Design \& fabrication of an active solar dryer for grape drying. M. Sc. Thesis. University of Shiraz.

EL-Amin, O. M. A; M. A. Ismail, E. A. Ahmed and W. Luecke (2005): Design and construction of a solar dryer for mango slices. Dept. of Agric. Eng., Faculty of Agriculture, University of Khartoum, Sudan.

Madhlopa, A., Jones, S.A and Kalenga Saka, J.D. (2002): A solar air heater with composite-absorber systems for food dehydration. Renewable Energy, 27: 27-37.

N.R.E.A. and U.S.A.I.D. (1991): "Egyptian solar radiation atlas" New and Renewable Energy Authority.

Singh, P. L; S. Ganesan and S. Singh (2005): Performance study of a solar tunnel dryer for horticultural crops. Proceedings of $39^{\text {th }}$ annual convention 
and symposium of Indian society of agricultural engineers. March 9-11, 2005.

Yahya, M; M. H. Ruslan, M. Y. Othman, B. Yatim, M. Y. Sulaiman, S. Mat, C. H. Lim, M. A. Alghoul, A. Zaharim and K. Sopian (2010): Evaluation of energy requirement for drying of green tea using a solar assisted drying system (V-groove solar collector). Proceedings of the $3^{\text {rd }}$ WSEAS Int. Conf. on Renewable Energy Sources, (2010).

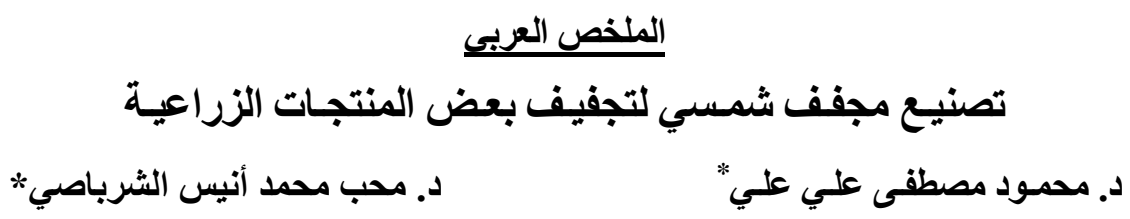

أجريـ التجربـة لتصـيع وتقييم جهاز للتجفيف بالطاقـة الثمسية،وذللك لتجفيف شـر ائح المـانجو وشـرائح البامية و النعناع خلال فصل صبف r I ـ ب في كلية الزر اعة ـ جامعة الزقازيق، تم تصنيع الجهاز في أحد

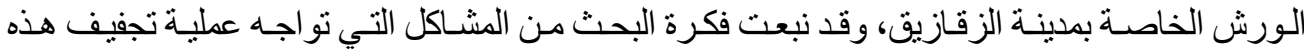

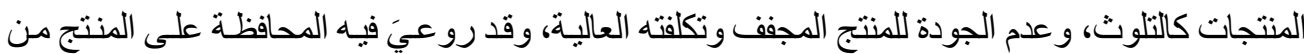

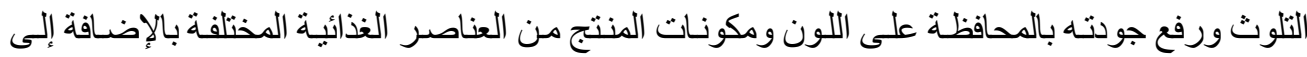
تقليل تكلفة عملية التجفيف. المجفف الشمسي: عبارة عن متوازي مستطيلات يأخذ من أعلى شكل مستطيل أبعاده ( • 7 × • ع) سم،

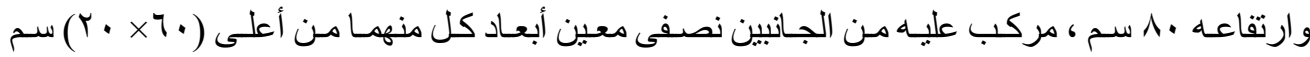

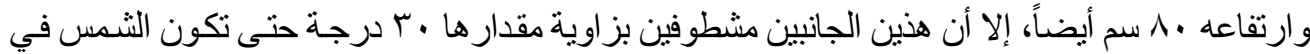

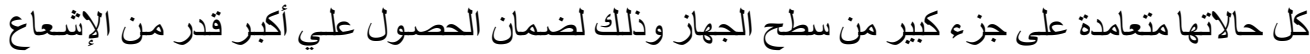

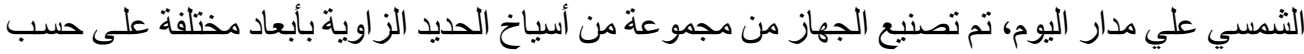

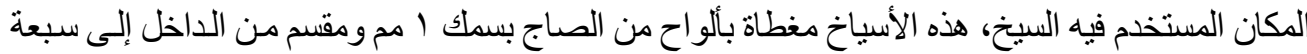

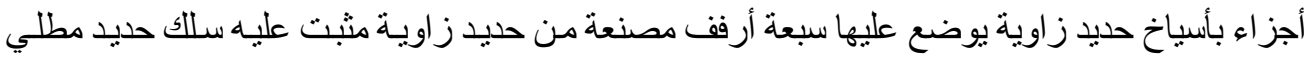

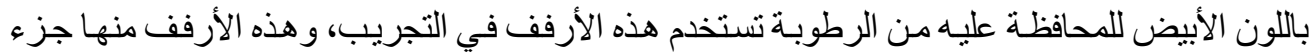

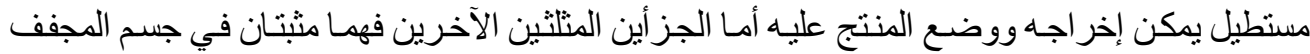

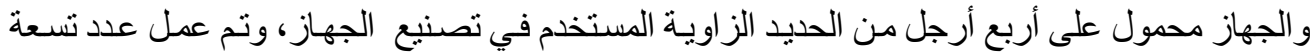

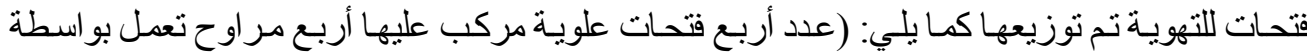

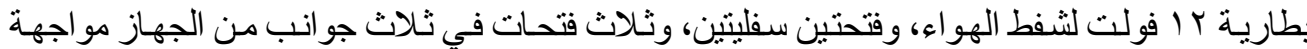
لاتجاه الرياح) تستخدم للتجريب.

أجريت مجموعتين من التجارب لكل منتج، وكل مجموعة تحتوى على 9 معاملات:

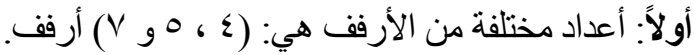

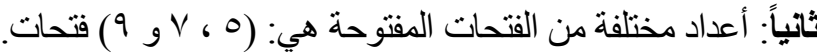

*'أستاذ مساعد - قسم الهندسة الزراعية ـ كلية الزراعة - جامعة الزقازيق - مصر. 


\section{وقد أظهرت النتائج المتحصل عليها ما يلي:}

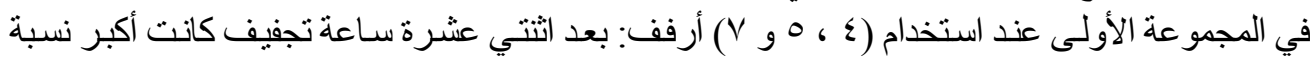

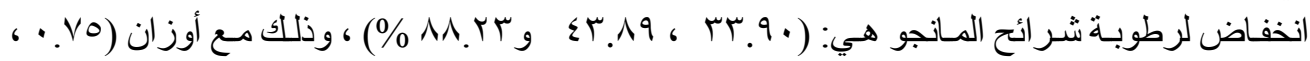

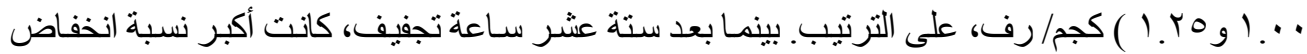

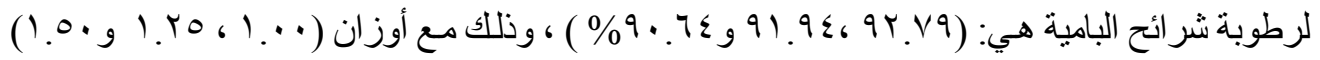
كجم / رف ، على الترتيب.

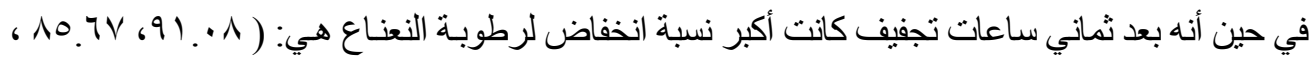

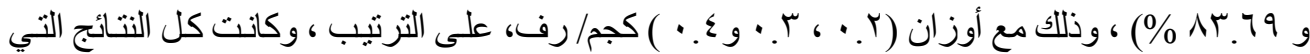

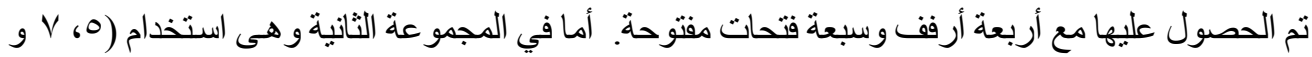

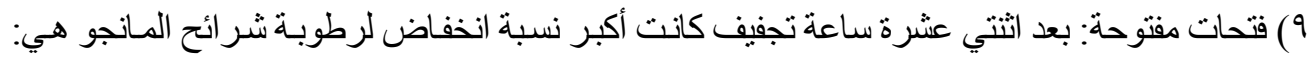

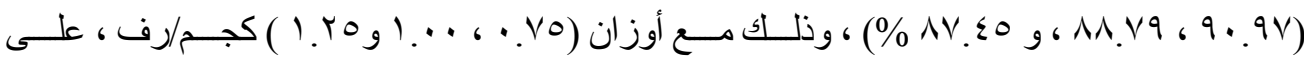

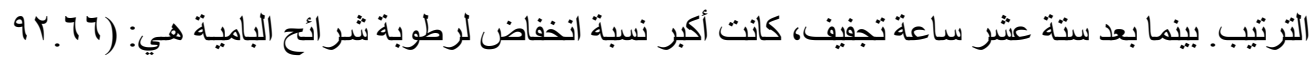

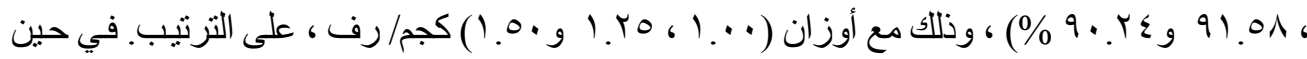

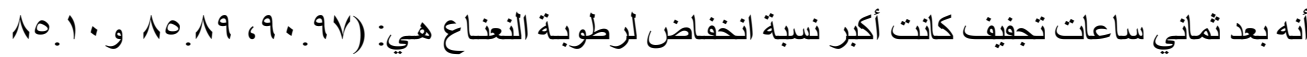

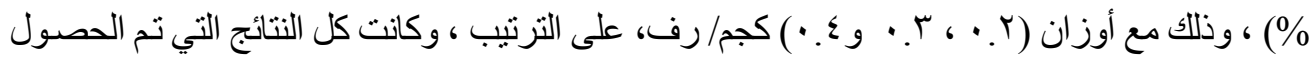

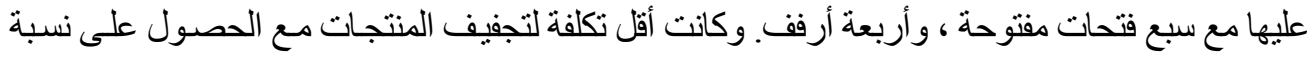

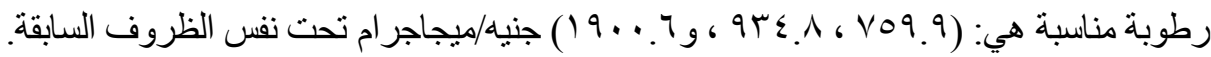

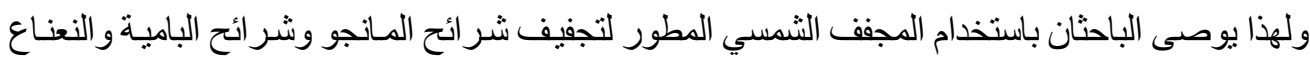

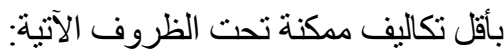

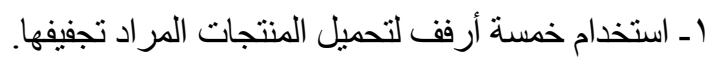

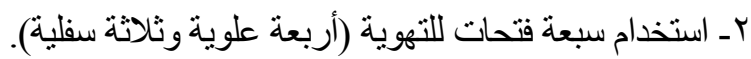

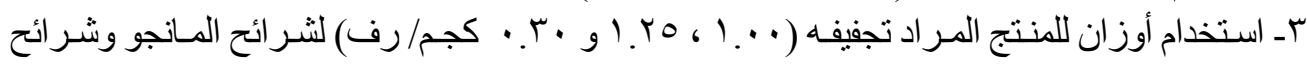
البامية و النعناع ، على التزتيب. 